\title{
PATENT ANALYSIS: A LOOK AT THE INNOVATIVE NATURE OF PLANT-BASED COSMETICS
}

\author{
Francine C. S. Césara, Fausto Carnevale Neto ${ }^{\mathrm{b}}$, Geciane S. Porto and Patrícia M. B. G. Maia Campos ${ }^{\mathrm{a}, *}$ \\ ${ }^{a}$ Departamento de Ciências Farmacêuticas, Universidade São Paulo, 14040-903 Ribeirão Preto - SP, Brasil \\ bDepartamento de Física e Química, Universidade São Paulo, 14040-903 Ribeirão Preto - SP, Brasil \\ 'Faculdade de Economia e Administração, Universidade São Paulo, 14040-905 Ribeirão Preto - SP, Brasil
}

Recebido em 01/12/2016; aceito em 26/01/2017; publicado na web em 24/02/17

\begin{abstract}
The use of plants have become a important trend in cosmetic market, with a crescent number of patent applications. Despite various herbal-based ingredients have been described in scientific literature, most of them are restricted to patent databases. In this work we analyze the innovative use of plants and its derivatives in cosmetic technologies, based on patent analysis. The investigation was conducted using Derwent World Patents Index (Thomson Reuters Scientific, USA) from 1995 to 2015. The search was carried out to evaluate the number of patent deposits, the patent depositors profiles, the countries with most patent applications, the International Patent Classification (IPC) and the main plant families using in cosmetics. Patent analysis revealed an increase number of applications involving cosmetic containing plants components, with a higher number of deposits related to anti-ageing and whitening skin treatment. Fabaceae, Asteraceae, Rosaceae, Lamiaceae, Poaceae, Rutaceae, Lilliacae and Apiaceae were the key plant families used in cosmetic formulations for skin care treatment. Comparison between scientific and technological data pointed out divergences between patents deposits and aid-based scientific reports. The use of patent analysis in combination with scientific data opens up wider aspects of knowledge and enables a better rationalization of innovative works.
\end{abstract}

Keywords: patents; plants; cosmetic; natural products; innovation.

\section{INTRODUCTION}

OECD (Organization for Economic Co-operation and Development) defines technological product and process (TPP) innovation as the introduction of a new or significantly improved product or process on the market. ${ }^{1}$ It involves a series of scientific, technological, organizational, financial and commercial activities, and ultimately provide to its owner a time-limit monopoly for the implementation and exploiting of invention, in the form of a patent. ${ }^{2,3}$

The patent is a legal intellectual property protection document that ensure rewards to the inventors for their intellectual efforts during a pre-determined period of time. ${ }^{3}$ Consequently, patent databases represent a extensive source of $R \& D$ and innovation outputs, as well as an indication of inventive countries achievement and diffuser tool of knowledge. ${ }^{4}$ Patent statistics also allows to know the dynamic of the innovative dissemination and possibly predict new technology demand. ${ }^{5}$

Since 1971, the patents have been indexed according to the International Patent Classification (IPC), established by the Strasbourg agreement. This categorization is composed of hierarchical levels, divided into sections, classes, groups and sub-groups, enabling the analysis of indexed technological parameters. ${ }^{6}$

Estimates show that $70 \%$ of the information contained in patents are not available in books, papers or other media. Thus, the analysis of patent is also important to identify technology trends, predict breaks in the intellectual property and to avoid researches duplication. ${ }^{7}$

In cosmetology, plant extracts, oils and waxes have become a prominent trend. ${ }^{8}$ First, characterized by mainstreaming ingredients in more holistic approaches, today herbal-based active ingredients have been described in scientific literature and applied in several cosmetic products, specially for skin treatment. ${ }^{8,9}$ Various phytochemicals have been proven to scavenge free radicals, to protect the skin matrix over the inhibition of enzymatic degradation or to promote collagen synthesis, affecting skin elasticity and hyper-pigmentation. ${ }^{8}$ Due to

*e-mail: pmcampos@usp.br their importance, natural products might display a high number of patents considering its application in cosmetics.

In this work we applied patent analysis to identify the use of natural products in cosmetic products, pointing the innovative trends in cosmetology and comparing different science and technology perspectives in the field. The results can guide the selection of potential plants from rich Brazilian biodiversity based on distinct scientific and technological aspects such as potential bioactivity, costs and commercial demand..$^{7,10,11}$

\section{METHODOLOGY}

Patent investigation was conducted using Derwent World Patents Index (Thomson Reuters Scientific, US) licensed by University of São Paulo. The study was carried out on natural products applications in cosmetology from 1995 to 2015, examining the number of patents, the date of deposit, depositor profile and International Patent Classification (IPC). It was utilized only the patents filled at the first application date in order to exclude repeated data, called here as "mother" patent.

We examined firstly the IPC A61Q subclass (Specific use of cosmetic or similar toilet preparations), then A61Q and A61K-008/97 (Similar cosmetic preparations for personal hygiene from vegetable origin) and finally A61Q-019* (Preparations for care of the skin) and A61K-008/97. Asterisk character code was used to retrieve all possible patents from "Preparations for care of the skin".

The information collected from IPC subclass and subgroups was analyzed to set a complete panel of the major countries-patent depositors and main applications of plants used in cosmetic patents.

A61Q-019 and A61K-008/97 subgroups were integrated with the scientific literature to compare both scientific and technological information retrieved for the main plants families and genera listed in A61K-036/00 subgroup "Medicinal preparations of undetermined constitution containing material from algae, lichens, fungi or plants, or derivatives thereof'. All group and subgroup studied are arranged 
on Tables 1-3. The search for detailed information concerning patent applications and plant families and genera was performed by the combination of specific IPC and the plant genera in patent title.

Table 1. Groups from subclass A61Q, according to IPC

A61Q-001/00 Make-up preparations; Body powders; Preparations for removing make-up

A61Q-003/00

Manicure or pedicure preparations

A61Q-005/00

Preparations for care of the hair

A61Q-007/00

Preparations for affecting hair growth

A61Q-009/00

Preparations for removing hair or for aiding hair removal

A61Q-011/00

Preparations for care of the teeth, of the oral cavity or of dentures, e.g. dentifrices or toothpastes; mouth rinses

A61Q-013/00

Formulations or additives for perfume preparations

A61Q-015/00

Anti-perspirants or body deodorants

A61Q-017/00

Barrier preparations; Preparations brought into direct contact with the skin for affording protection against external influences, e.g. sunlight, X-rays or other harmful rays, corrosive materials, bacteria or insect stings

A61Q-019/00 Preparations for care of the skin

Table 2. Subgroups from A61Q-019/00, according to IPC

\begin{tabular}{ll}
\hline A61Q-019/02 & $\begin{array}{l}\text { for chemically bleaching or whitening the skin } \\
\text { for chemically tanning the skin }\end{array}$ \\
A61Q-019/04 & for countering cellulitis \\
A61Q-019/06 & Anti-ageing preparations \\
A61Q-019/08 & Washing or bathing preparations \\
\hline
\end{tabular}

Table 3. Subgroups from A61K-036/00, according to IPC

\begin{tabular}{ll}
\hline A61K-036/48 & Fabaceae or Leguminosae \\
A61K-036/28 & Asteraceae or Compositae \\
A61K-036/73 & Rosaceae \\
A61K-036/899 & Poaceae or Gramineae \\
A61K-036/53 & Lamiaceae or Labiatae \\
A61K-036/896 & Liliaceae \\
A61K-036/23 & Apiaceae or Umbelliferae \\
A61K-036/75 & Rutaceae \\
\hline
\end{tabular}

\section{RESULTS AND DISCUSSION}

Subclass A61Q (Specific Use of Cosmetic or Similar Toilet Preparations) yielded 72611 "mother" patent - filled at the first application date - on the Derwent database from 1995 to 2015 . From these, $32 \%$ were classified in subgroup A61K-008/97, which refers to "Cosmetics or similar toilet preparations of vegetable origin".

Considering the number of patents in this IPC subgroup, it was observed an increase in the use of natural products, per year, in cosmetics using plants, during last 10 years, up to $49 \%$ in 2015 , as shown in Figure 1.

The result evidenced the importance of natural products in cosmetics field, connecting research activities to wider economic usage through technology and innovation, in reflection of an increased focus on environmental sustainability. ${ }^{12,13}$

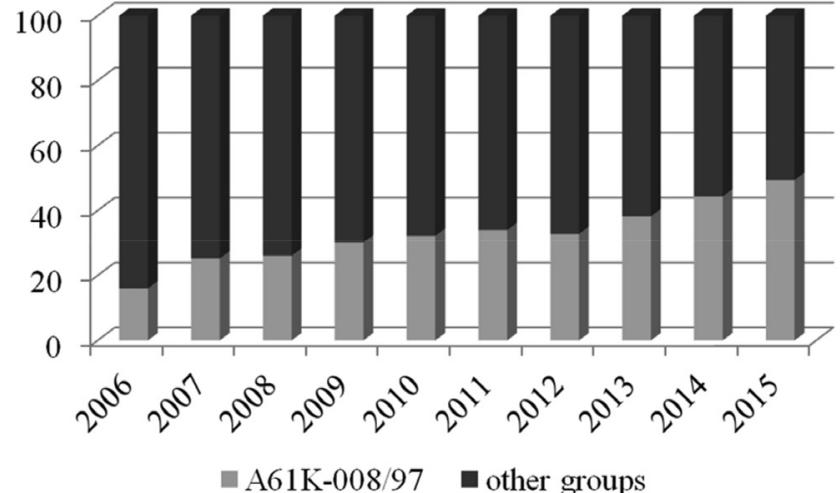

Figure 1. Perceptual of patent depositor containing materials from vegetable origin

According to total number of patents by IPC classifications, as depicted in Figure 2, most patent applications are related to preparations for skin care, followed by hair treatment and makeup, using or not ingredients from plant origin.

\section{Number of Patents classified by IPC}

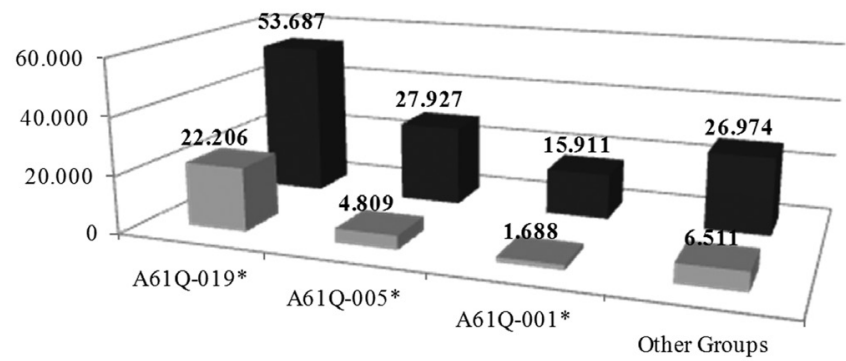

- PATENT COSMETICS FROM VEGETABLE SOURCES - PATENTS COSMETIC

Figure 2. Relevance of cosmetic patents per group

Since most cosmetic patents were related to skin treatment, a detailed search was performed to characterized the use of plants in this cosmetic application (main countries with patent application, main skin treatments applications and principal plant families and genera). The search initiated by combining IPCs A61Q-019* and A61K-008/97 and resulted in 16801 patents, and showed the number of patent applications for skin treatment using plants based on the main countries of the patent office's (Figure 3).

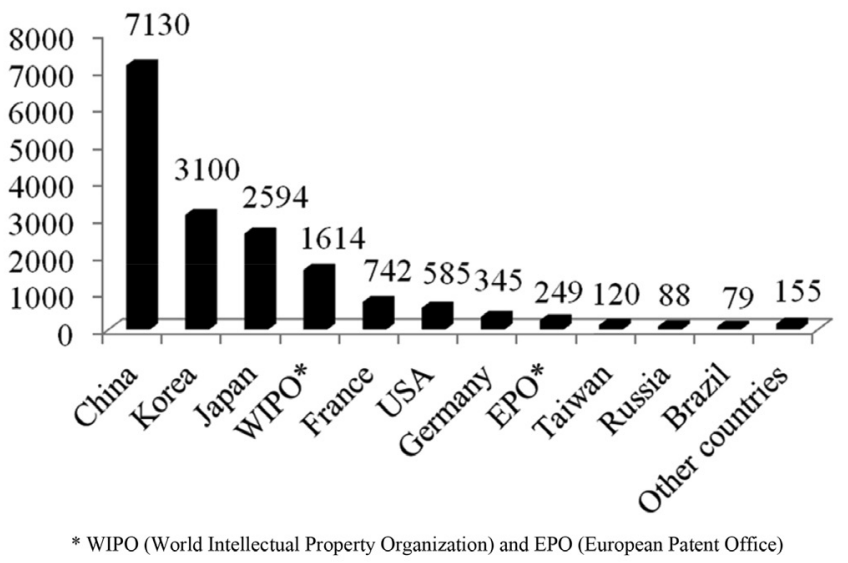

Figure 3. The main countries with cosmetic patent application for skin treatment using plants 
The priority country shows the first place the patent was deposited. This information might indicate technologies head offices`origins and reveal the interest in protecting certain innovation in a particular market. ${ }^{10}$

The graphic of Figure 3 revealed that China is the country with the largest number of patents using plants in cosmetics preparations, followed by South Korea. France appears in $5^{\text {th }}$ with 742 applications, whereas Brazil occupy the $11^{\text {th }}$ with 79 patents.

The relevant number of patent applications in Asiatic countries can be explained by the widespread use of natural products, where herbal-based therapies are essential part of the healthcare system, ${ }^{10}$, 13,14 even with rigorous local regulations to ensure the quality, efficacy and safety of herbal products at international level. ${ }^{15}$ Chinese legislation regulate the use of plants in cosmetics in a similar way to chemical drugs and biological products, requiring technical evaluations and clinical trials for new with anti-pigmentation, spot, melanin, sunscreens, slimming, breast care, hair growth, hair colors, perms, deodorant and depilatories cosmetics. ${ }^{15,16}$ South Korea also requests high quality, safe and efficacy standards for registration of medicinal herbs and 'functional cosmetics as sunscreens, antiwrinkles and whitening formulations. ${ }^{15,16}$

A further analysis of the main patent head office's revealed that 1061 patent deposits were done by universities. Among companies, Korean Amore Pacific was the most significant depositor $(n=428)$, followed by French Loreal $(\mathrm{n}=255)$ and Japanese Kao Corp $(\mathrm{n}=228)$. In Brazil, 11 applications from the 79 patents came from universities. Currently, public policy has encouraged innovation in universities and also transference of technology to the industry. Still, the low number of patent deposits evidenced the need of greater effort in explore Brazilian rich biodiversity and turn the knowledge in innovative applications, especially in cosmetic field..$^{13,17}$

The number of patent applications retrieved in a combination of IPC A61Q-019* (Preparations for care of the skin) and A61K-008/97 (Similar cosmetic preparations for personal hygiene from vegetable origin) from 1995 to 2015 showed that $41 \%$ of cosmetic patents for skin treatment from plant origins were related to anti-aging preparations (A61Q-019/08), 34\% to skin whitening (A61Q-019/02), 20\% to bath preparations, 3\% for the treatment of cellulite (A61Q-019/06) and 2\% for skin tanning (A61Q-019/04), as depicted in Figure 4a. Based on the last 5 years (2010-2015), it is also observed a sharp increase in number of patents deposits for anti-aging and whitening skin treatments, as in Figure $4 \mathrm{~b}$. Contrariwise, there is a small reduction in the development of plant-based products to treat cellulite, despite recent reports describing plants as effective ingredients against several pathological steps involved in this pathogenesis..$^{14,18,19}$

The analysis of patent applications was also performed based on taxonomic classification of the plants used in the cosmetic formulations. The results showed that most plant-based patent applications in "Preparations for care of the skin" category are angiosperms $(n=2004)$, followed by ginkgophyta $(n=49)$ and gymnosperms $(n=42)$. Angiosperms are terrestrial plants whose seeds are protected by fruits. Its predominance in plant-based patents can be justified because they correspond to the largest and most modern plant group with approximately 250000 species. $^{20}$

Since angiosperm was by far the largest group associated with "Preparations for care of the skin", we analyzed the patent applications for the most relevant families and genera. According to Dewert's database, there are 634 patent applications on Fabaceae, 507 on Asteraceae, 477 on Rosaceae, 372 on Lamiaceae, 344 on Poaceae, 306 on Rutaceae, 284 on Lilliacae and 233 on Apiaceae. These data were compared with the total of scientific reports on Web of Science database during the same period (1995-2015). The search was performed using the terms "skin treatment" and the main genera. The total number of patent applications and scientific reports for the main genera for each plant family are depicted in Table 4 . Prominent bioactive phytochemicals in skin care treatment are shown in Figure 5.

In some cases, a large number of scientific publications validating the potential bioactivity have not been converted into patents. In others, some genera with large number of patent applications have not attracted the same interest for scientific community. This dissemblance might be related to major differences between science and technology. In science, there is a constant need for more evaluation and more clinical studies in vivo with emphasis on the ingredient concentration of the plant/herbal products, its formulation, safety, and duration of effect. In technology, there is a seek to discourage competition in innovation by claiming a broad scope of patent protection for their inventions. ${ }^{21} \mathrm{In}$ case of cosmetics containing material of vegetable origin, this means include all possible applications of the plant without specifying the part of the plant used in the formulation, the type of extraction and/or the bioactive chemical compounds. Furthermore, the success in business innovation requires constraints such as productivity and costs, which means not only determine the bioactive compounds, but also envisage market acceptance, productivity and costs.

Fabaceae, or Leguminosae, contains 727 genera and 19325 species, widely use in production of gums, dyes, thickeners, medicines, resins and pesticides. ${ }^{14}$ According to our search, the genera Glyzyrriza and Shophora showed the higher number of patents related to Fabaceae, with 64 and 21 patent, respectively. Both genera have considerable anti-melanogenic potential and might be an important source of active ingredients for cosmetics with whitening action of skin blemishes. ${ }^{18,19}$ Shophora flavecens roots has anti-melanogenic activity due to kuraridin (1), a)

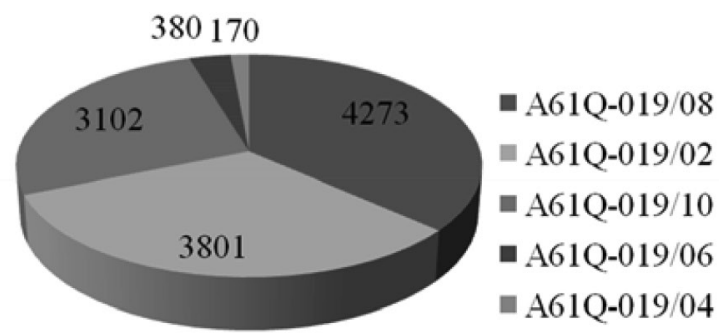

b)

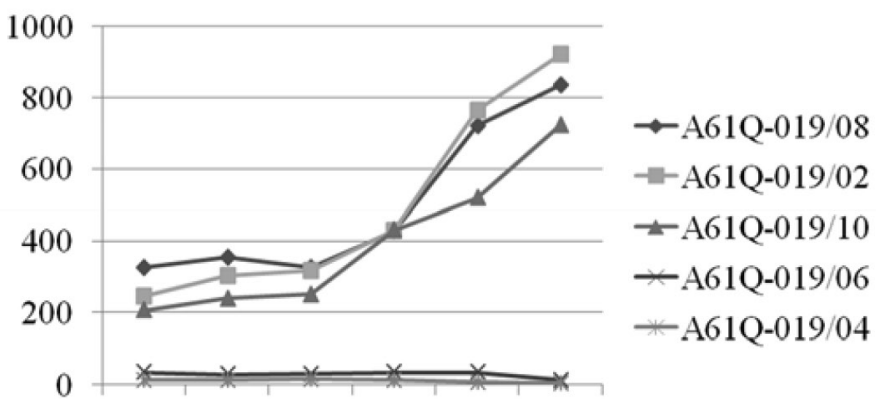

201020112012201320142015

Figure 4. a) Relevance of cosmetic patents for skin treatment from plant origins and b) tendency graph between 2010-2015. A61Q-019/02: chemically bleaching or whitening the skin, A61Q-019/04: chemically tanning the skin, A61Q-019/06: cellulite treatment, A61Q-019/08: anti-ageing preparations, and A61Q-019/10: washing or bathing preparations 
Table 4. Number of patent applications in "Preparations for care of the skin" classified by plant families and genera

\begin{tabular}{|c|c|c|c|c|}
\hline Plant family & IPC & Genus & $\mathrm{N}^{\circ}$ of patents & $\mathrm{N}^{\circ}$ of citations Web of Science \\
\hline \multirow{8}{*}{ FABACEAE } & A61K-036/484 & Glycyrrhiza & 64 & 72 \\
\hline & A61K-036/489 & Sophora & 21 & 129 \\
\hline & A61K-036/482 & Cassia & 15 & 99 \\
\hline & A61K-036/481 & Astragalus & 14 & 152 \\
\hline & A61K-036/488 & Pueraria & 14 & 17 \\
\hline & A61K-036/483 & Gleditsia & 8 & 13 \\
\hline & A61K-036/487 & Psoralea & 4 & 24 \\
\hline & A61K-036/486 & Millettia & 3 & 2 \\
\hline \multirow{6}{*}{ ASTERACEAE } & A61K-036/282 & Artemisia & 31 & 84 \\
\hline & A61K-036/284 & Atractylodes & 10 & 75 \\
\hline & A61K-036/286 & Carthamus & 9 & 15 \\
\hline & A61K-036/287 & Chrysanthemum & 8 & 81 \\
\hline & A61K-036/285 & Aucklandia & 7 & 3 \\
\hline & A61K-036/288 & Taraxacum & 6 & 21 \\
\hline \multirow{5}{*}{ ROSACEAE } & A61K-036/736 & Prunus & 77 & 140 \\
\hline & A61K-036/738 & Rosa & 32 & 41 \\
\hline & A61K-036/732 & Chaenomeles & 7 & 1 \\
\hline & A61K-036/734 & Crataegus & 6 & 11 \\
\hline & A61K-036/739 & Sanguisorba & 6 & 34 \\
\hline \multirow{8}{*}{ LAMIACEAE } & A61K-036/534 & Mentha & 25 & 32 \\
\hline & A61K-036/537 & Salvia & 25 & 119 \\
\hline & A61K-036/539 & Scutellaria & 21 & 80 \\
\hline & A61K-036/535 & Perilla & 12 & 36 \\
\hline & A61K-036/533 & Leonurus & 11 & 6 \\
\hline & A61K-036/532 & Agastache & 4 & 4 \\
\hline & A61K-036/538 & Schizonepeta & 3 & 16 \\
\hline & A61K-036/536 & Prunella & 2 & 14 \\
\hline \multirow{2}{*}{ POACEAE } & A61K-036/8994 & Coix & 23 & 33 \\
\hline & A61K-036/8998 & Hordeum & 14 & 4 \\
\hline \multirow{4}{*}{ RUTACEAE } & A61K-036/752 & Citrus & 109 & 195 \\
\hline & A61K-036/756 & Phellodendron & 24 & 66 \\
\hline & A61K-036/758 & Zanthoxylum & 11 & 18 \\
\hline & A61K-036/754 & Evodia & 3 & 10 \\
\hline \multirow{7}{*}{ LILIACEAE } & A61K-036/8962 & Allium & 33 & 76 \\
\hline & A61K-036/8969 & Polygonatum & 13 & 14 \\
\hline & A61K-036/8967 & Lilium & 11 & 10 \\
\hline & A61K-036/8968 & Ophiopogon & 10 & 20 \\
\hline & A61K-036/8965 & Asparagus & 8 & 21 \\
\hline & A61K-036/8966 & Fritillaria & 4 & 6 \\
\hline & A61K-036/8964 & Anemarrhena & 3 & 14 \\
\hline \multirow{5}{*}{ APIACEAE } & A61K-036/232 & Angelica & 38 & 293 \\
\hline & A61K-036/236 & Ligusticum & 11 & 27 \\
\hline & A61K-036/234 & Cnidium & 5 & 53 \\
\hline & A61K-036/233 & Bupleurum & 3 & 20 \\
\hline & A61K-036/235 & Foeniculum & 3 & 14 \\
\hline
\end{tabular}

sophoraflavanone G (2), kurarinone (3), and kushenol A (4). ${ }^{22-25}$ The roots of Glycyrrhiza glabra, popularly known as liquorice, also demonstrated anti-inflammatory properties and promotes cell renewal due to glycyrrizic acid (5), glabridin (6) and liquiritin (7) ${ }^{26-}$ ${ }^{28}$ Glycyrrhizic acid also prevented photo-aging due to inhibition of hyaluronidase. ${ }^{8}$ The anti-inflammatory and anti-oxidative properties of licochalcone A (8), present in the roots of Glycyrrhiza species have been described as effective to treat acne. ${ }^{26,29-31}$ Interestingly, Pueraria showed an equivalent number of patents and scientific articles. According to literature, Pueraria species have potential skin regenerative activity, however their bioactive compounds remain unknown. ${ }^{32}$ In Dewert's database, we found patent applications describing the use of Pueraria plant species in cosmetic preparations for rejuvenating skin, ${ }^{33}$ treating skin inflammation, ${ }^{34}$ for quench free radicals and lightening the skin $^{35}$ and to soothe skin. ${ }^{36}$ Glyzyrriza and Shophora have also been used in emulsions, gels, lotions and suspensions containing their crude extracts or phytochemicals for the treatment of skin hyperpigmentation. ${ }^{37-39}$

Glyzyrriza also has been described in patents for the treatment of acne-prone skin ${ }^{40}$ and atopic dermatitis ${ }^{41,42}$ whereas Shopora has 
<smiles>C=C(C)C(CC=C(C)C)Cc1c(O)cc(OC)c(C(=O)/C=C/c2ccc(O)cc2O)c1O</smiles><smiles>C=C(C)C(CC=C(C)C)Cc1c(O)cc(O)c2c1OC(c1ccccc1O)CC2=O</smiles>

(4)<smiles>O=C1CC(c2ccc(OC3OC(CO)C(O)C(O)C3O)cc2)Oc2cc(O)ccc21</smiles>

(7)<smiles>C=C(C)C(CC=C(C)C)Cc1c(O)cc(O)c2c1O[C@H](c1ccc(O)cc1O)CC2=O</smiles>

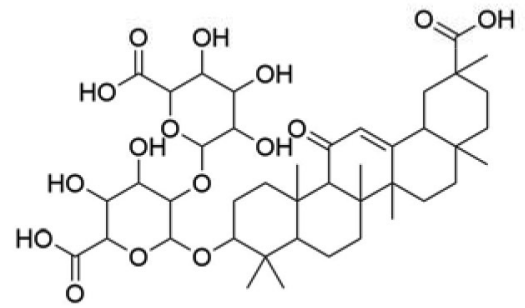

(5)<smiles>C=CC(C)(C)c1cc(/C=C/C(=O)c2ccc(O)cc2)c(O)cc1OC</smiles>

(8)<smiles>C=C(C)C(CC=C(C)C)Cc1c(O)cc(OC)c2c1OC(c1ccc(O)cc1O)CC2=O</smiles>

(3)<smiles>CC1(C)C=Cc2c(ccc3c2OCC(c2ccc(O)cc2O)C3)O1</smiles>

(6)<smiles>CC1CCC2(C(=O)OC3OC(COC4OC(CO)C(OC5OC(C)C(O)C(O)C5O)C(O)C4O)C(O)C(O)C3O)CCC3(C)C(=CCC4C3CCC3C(C)(CO)C(O)C(O)CC43C)C2C1C</smiles>

(12)<smiles>CC1CCC(C(C)C)C(O)C1</smiles>

(9)<smiles>CC1CCC(C(C)C)C(=O)C1</smiles>

(10)<smiles>C=CCSS(=O)CC=C</smiles>

(11)

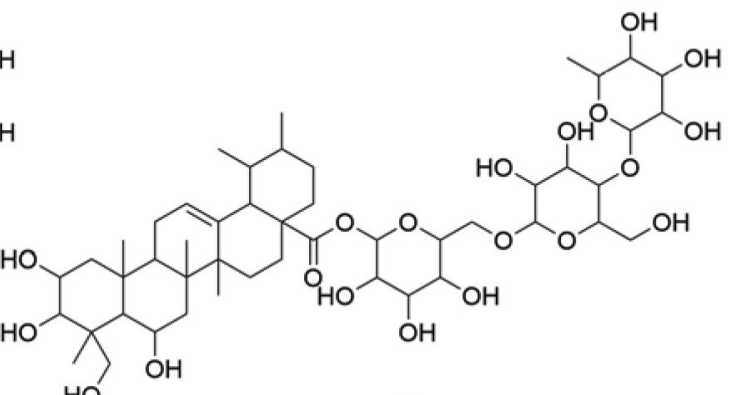

(13)<smiles>CC1CCC2(C(=O)O)CCC3(C)C(=CCC4C(CC3(C)C)C3C4C(O)CC(O)C(O)C3(C)CO)C2C1C</smiles><smiles>CC(C)=CCOc1c2ccoc2cc2oc(=O)ccc12</smiles>

(15)<smiles>CC(C)=CCOc1c2occc2cc2ccc(=O)oc12</smiles>

(16)

Figure 5. Prominent bioactive phytochemicals with potential in skin care treatment

been utilized for vaginal cleaning products, for itching and stretch marks treatments, ${ }^{43,44}$ quenching free radicals ${ }^{45}$ and preventing or treating atopic dermatitis. ${ }^{46}$

Asteraceae comprises a high number of flowering plants, grouped in nearly 1600 genera gathering 23000 species. ${ }^{26}$ Some examples as wormwood (Artemisia absinthium), sunflower (Helianthus annus), chrysanthemum (Chrysanthemum sp.), daisy (Bellis perenis), calendula (Calendula officinalis) and chamomile (Matricaria recutita) are highly aromatic and were previously reported as medicine herbals. ${ }^{47}$ Their chemical composition comprise mainly triterpenes and the carotenoids flavoxantin, auroxantin, lutein, zeaxanthin and beta-carotene (with antioxidant properties and yellow-orange color). Plants from this family are important to cosmetics science due to the presence of resins and essential oils, especially Artemisia species, with 31 patents in our search. ${ }^{48-50}$ In patent database, Artemisia has been used for whitening skin, ${ }^{51-53}$ to reduce excess adipose and/or cellulite $^{54}$ and for delaying aging and masking wrinkles. ${ }^{55}$

Rosaceae corresponds to 100 genera and 2000 ornamentals plants species as roses (Rosa sp.) or fruit trees like plums, cherries, peaches, apricots and almonds (Prunus). ${ }^{26}$ Chemical composition exhibited a large amount of phenolic compounds with antioxidant activity, in addition to essential oils in flowers and exudate gum in Prunus species. ${ }^{27,56}$ The search evidenced the importance of Prunus and Rosa genera with 77 and 32 patents, respectively. Chaenomeles have been described in 7 patent applications during 1995-2015, however only one study discussed its potential in a screening of 100 plant extracts as melanogenesis inhinitors. ${ }^{22}$ Among the patent applications related to Rosaceae, we detected the application of plants extracts to treat acne rosacea, ${ }^{57}$ for soothing skin irritated ${ }^{58}$ and caring aged skin or aged hair. ${ }^{59}$ In case of Chaenomeles, it has been described its use to 
prevents skin aging, masks wrinkles and improves skin elasticity. ${ }^{60}$ Additionally, Chaenomeles has been described in patents due to antiseborrheic ${ }^{61}$ and free radical scavenger activities. ${ }^{62}$ There is no patent application related to antimelatogenic activity.

Lamiaceae includes 250 genera and 7000 species, divided into 7 subfamilies..$^{20}$ Plants from this family are important for the extraction of essential oils used in cosmetic and/or medicinal industries (Mentha, Lavandula, Marrubium, Nepeta, Ocimum, Origanum, Rosmarinus, Salvia, Satureja, Thymus etc.). ${ }^{56}$ The search highlighted the importance of Salvia and Mentha in applications for skin care, with 25 patents each. Mentha oils usually contains mixture of monoterpenes menthol (9) and menthone (10) possess skin conditioning properties, pleasing odor and helps to soothe dry, itchy irritated skin due to allergies or contact dermatitis. ${ }^{63}$

Based on patent applications, Mentha has been applied in formulations to treat acne, ${ }^{58}$ slimming and firming skin ${ }^{59}$ and to increase skin fatty tissue in dermatological surgeries. ${ }^{64}$ Salvia extracts have been added to topical formulations for whitening skin ${ }^{65,66}$ and anti-aging, besides the uses to restore softness and luminosity, and to treat cellular aging induced by radiotherapy and chemotherapy. ${ }^{67}$

Poaceae, the "grass family", is composed by 668 genera and 10035 species that produce grains and cereals such as wheat (Triticum spp.), rye (Secale cereale), barley (Hordeum vulgare), oats (Avena sativa), rice (Oryza) and corn (Zea), in addition to sugarcane (Saccharum) and bamboo (Bambusoideae). ${ }^{14,20,50}$ Interestingly, the search showed 23 patents related to Coix species and 14 patents to Hordeum. Coix is a genus of Asian and Australian plants in the grass family where Coix lacryma-jobi (popular name Job's tears) is the best-known species. Recent publications demonstrated Job's tears have been used for the treatment of edema, rheumatism, and neuralgia and its oral use has also prevented skin diseases as dry skin or atopic dermatitis. Its mechanism of action was related to recovery of skin barriers by an increase in ceramide content. ${ }^{68-73}$

Barley (Hordeum vulgare) has been widely used as active ingredient in cosmetics formulations as skin conditioning because of its hydrolyzed proteins. However, barley has also been associated as antioxidant due to the presence of vanillic acid, $p$-coumaric acid, $p$-hydroxyl-benzoic acid, $p$-hydroxy-benzaldehyde, quercetin, 3,4-dihydroxy-benzaldehyde and other phenol metabolites. ${ }^{68-70}$

Coix genus has been described mainly in patent applications for skin whitening,${ }^{72}$ for wrinkle removal ${ }^{73}$ and to treat skin inflammation and alopecia. ${ }^{74}$ Hordeum genus has also been applied because of its antiproteolytic activity, fibroblast proliferation stimulation, skin inflammation inhibition ${ }^{75}$ and to provide moisturization of keratinous substrates. $^{76}$

Liliaceae has 15 genera and up to 635 species used as ornamental plants due to their flowers, as Tulipa, Fritillaria, Lilium and Erythronium. In cosmetology the genus Aloe is important because of Aloe vera, plant species with recognized emollient properties. ${ }^{18,56,77}$ According to the search, the most expressive genus was Allium, with 33 patent applications, from a total of 82 applications. Allium species such as Allium sativa possess great importance for cosmetic area since they show ability to suppress lipogenesis, one of the mechanisms suggested to treat cellulite. Besides, allicin (11) has antimicrobial and antioxidant properties, useful for skin care and antiaging preparations. ${ }^{78-80}$ Allium has been applied in patents for the treatment of cellulite, ${ }^{81}$ wrinkles, aging, ${ }^{82}$ inflammation ${ }^{83}$ and to prevent hair loss. ${ }^{84}$

Apiaceae consists of 300 genera and more than 3000 species of aromatic plants such as parsley (Petroselinum crispum), anise (Pimpinella anisum), angelica (Angelica archangelica) and carrot (Daucus carota).$^{20}$ Its use in cosmetic field is related to aromatic plant`s essential oils mainly from anise, fennel (Foeniculum vulgare) and angelica, and because of anti-cellulite use of Centella asiatica. ${ }^{56}$ C. asiatica have been indicated for the treatment of photoaging skin, cellulite and striae due the presence of active pentacyclic triterpenes, mainly asiaticoside (12), madecassoside (13) and madecassic acid (14). ${ }^{85}$ However, data analysis demonstrated most patents from this family are related to Angelica genus (38 patents from a total of 60), probably due to popular usage of Angelica dahurica in cosmetic products. ${ }^{86}$ Previous work identified active isoimperatorin (15) and imperatorin (16) from Angelica dahurica that inhibited tyrosinase synthesisin B16 melanoma cells, related to skin spots and melasma. ${ }^{86,87}$

Patent applications indicated the use of Angelica plant species to treat atopic dermatitis, pruritus and spots. ${ }^{88}$ In Dewert database we found the use of Angelica dahurica in a selenium-enriched cosmetic preparation, ${ }^{89}$ Angelica gigas oil extract to reduce body fat and cellulite, ${ }^{90}$ ceramide generation accelerator ${ }^{91}$ and as preparation for removing freckle and preventing wrinkle. ${ }^{92}$

Rutaceae is a family with 150 genera and 2000 species. $^{20}$ According to results, Citrus had the highest number of patent application (109). Citrus plants have several active compounds, most flavonoids and polyphenols with a large spectrum of biological activities including antibacterial, antifungal, hypoglycemiant and antiviral activities and its use in cosmetic is related to fragrance (fruits extracts), skin conditioning and adstringent (fruit oil). ${ }^{93,94}$ Citrus applications in patents have been related to formulations to treat inflammation ${ }^{95}$ and skin infecitions, ${ }^{96-98}$ to reduce the appearance of dark circles, puffiness and sagginess in the periorbital area, ${ }^{98}$ as fragrances and aromatic essence used as aromatherapy oil. ${ }^{99}$

According to the results, most patent applications of cosmetics for skin treatment describe the use of plants in the form of herbal extracts or pure bioactive ingredients in creams, lotions or gels. Additionally, most patented formulations use a combination of plant extracts. Although these patents have a broad scope in an attempt to strengthen patent protection, ${ }^{21}$ its analysis can bring relevant information regarding discoveries with immediate impact in technological innovation that is not shared in the scientific literature, for instance, the understanding of synergistic and antagonistic relationships in complex matrices. ${ }^{100}$

\section{CONCLUSION}

The study evidenced the increase of natural products in cosmetics field reaching a large number of patent applications every year than traditional cosmetics. This may be driven by the increased focus on environmental sustainability trends, suggesting the search for new products in the coming years.

Anti-aging and whitening skin appeared as the most patented products pointing this category as an opportunity to develop new products due to the desire of people in maintaining young appearance with the life expectation's increase specially in Asiatic countries even with the restricted control to the market of these products. Search on Derwent database revealed that natural products have been applied in cosmetics as active ingredient in form of extract and/or phytocompound added to a creams, lotions, suspensions or gels. We highlighted the main family and genera applied to cosmetic patents and evaluated the information regarding its biological activity in literature and in patent database and the results showed that information were complementary and may provided a better understating of potential herbs considering the future trends of this technology as bioactivity and commercial demand.

\section{ACKNOWLEDGEMENTS}

The authors thank to Coordenação de Aperfeiçoamento de Pessoal 
de Nível Superior (CAPES), Conselho Nacional de Desenvolvimento Cientifico e Tecnológico (CNPq) and Fundação de Amparo à Pesquisa do Estado de São Paulo (FAPESP) for project grant and fellowship support (F.C.N. FAPESP grant $n^{\circ}$ 2014/12343-2).

\section{REFERENCES}

1. OECD-EUROSTAT; Oslo Manual: Guidelines for collecting and interpreting technological innovation data. 3th ed.; OECD Publishing: Paris, 2005.

2. OECD-EUROSTAT; Oslo Manual: The measurement of scientific and technological activities: proposed guidelines for collecting and interpreting technological innovation data, $2^{\text {nd }}$ ed., OECD Publishing: Paris, 1997.

3. de Oliveira, L.; Suster, R.; Pinto, A.; Ribeiro, N.; da Silva, R.; Quim. Nova. 2005, 28, 36 .

4. OECD-EUROSTAT In OECD patent statistics manual; OECD Publishing: Paris, 2009, ch. 2.

5. Dernis, H. In OECD Science, Technology and Industry Working Papers, OECD Publishing: Paris, 2007, 48.

6. http://ipc.inpi.gov.br/ipcpub/static/pdf/guia_ipc/br/guide/guide_ipc.pdf, accessed in January, 2017.

7. Pereira, C. G.; da Silva, R. R.; Porto, G. S.; Braz. J. Sci. Tech. 2015, 2 , 2.

8. Binic, I.; Lazarevic, V.; Ljubenovic, M.; Mojsa, J.; Sokolovic, D.; Evid. Based Complement. Alternat. Med. 2013, ID 827248.

9. Mukherjee, P. K.; Maity, N.; Nema, N. K.; Sarkar, B. K.; Phytomedicine 2011, 19, 64.

10. Amaral, L. F. G.; Fierro, I. M.; Braz. J. Pharmacog. 2013, 23, 716.

11. de Castro Correa, E.; Temática 2015, 11, 155.

12. Guaratini, T.; Callejon, D. R.; Pires, D. C.; Lopes, J. N. C.; Lima, L. M.; Giannella Neto, D.; Sustovich, C.; Lopes, N. P.; Quim. Nova 2009, 32, 717.

13. Fonseca-Santos, B.; Corrêa, M. A.; Chorilli, M.; Braz. J. Pharm. Sci. 2015, 51, 17.

14. Aburjai, T.; Natsheh, F. M.; Phytother. Res. 2003, 17, 987.

15. Fan, T.-P.; Deal, G.; Koo, H.-L.; Rees, D.; Sun, H.; Chen, S.; Dou, J.-H.; Makarov, V. G.; Pozharitskaya, O. N.; Shikov, A. N.; J. Ethnopharmacol. 2012, 140, 568 .

16. Pisacane, G.; Household Pers. Care Today 2009, 4, 21.

17. Barreiro, E. J.; Bolzani, V. d. S.; Quim. Nova 2009, 32, 679.

18. Sharma, L.; Agarwal, G.; Kumar, A.; Indian Journal of Traditional Knowledge 2003, 2, 62.

19. Distante, F.; Bacci, P.; Carrera, M.; Int. J. Cosmet. Sci. 2006, 28, 191.

20. Kenrick, P.; Nature 1999, 402, 358.

21. Mull, W. C.; Health Matrix 2004, 14, 393.

22. Lee, K.; Kim, B.; Kim, J.; Heo, M.; Kim, H.; Int. J. Cosmet. Sci. 1997, 19, 291.

23. Shin, D. H.; Cha, Y. J.; Joe, G. J.; Yang, K. E.; Jang, I.-S.; Kim, B. H.; Kim, J. M.; Pharm. Biol. 2013, 51, 1467.

24. Kim, S. J.; Son, K. H.; Chang, H. W.; Kang, S. S.; Kim, H. P.; Biol. Pharm. Bull. 2003, 26, 1348.

25. Hyun, S. K.; Lee, W.-H.; Jeong, D. M.; Kim, Y.; Choi, J. S.; Biol. Pharm. Bull. 2008, 31, 154.

26. Nand, P.; Drabu, S.; Gupta, R.; Indian J. Nat. Prod. Resour. 2012, 3, 28.

27. Asl, M. N.; Hosseinzadeh, H.; Phytother. Res. 2008, 22, 709.

28. Kim, B.; Kim, J.; Kim, H.; Heo, M.; Int. J. Cosmet. Sci. 1997, 19, 299.

29. Kolbe, L.; Immeyer, J.; Eggers, K.; Neufang, G.; J. Am. Acad. Dermatol. 2006, 54, AB101.

30. Shibata, S.; Inoue, H.; Iwata, S.; Ma, R.; Yu, L.; Ueyama, H.; Takayasu, J.; Hasegawa, T.; Tokuda, H.; Nishino, A.; Planta Med. 1991, 57, 221.

31. Capasso, F.; Mascolo, N.; Duraccio, M.; J. Pharm. Pharmacol. 1983, 35,332 .
32. Kim, D.; Won, K.; Hwang, D.; Yoon, S.; Lee, S.; Park, J.; Yoon, M.; Kim, B.; Lee, H.; Nat. Prod. Commun. 2015, 10, 2009.

33. Lee, H. M.; Kim, D. Y.; Yoon, M. S.; KR2015104916-A 2014.

34. Perrier, E.; Bonnet, S.; Rival, D.; US2015110907-A1 2002.

35. Gwon, C. H.; Yeon, K. S.; Byeol, H. E.; KR1434163-B1 2013.

36. Sam, S. M.; KR2011038540-A 2009.

37. Park, J. S.; Shim, J. S.; Hwang, K. H.; KR2012118946-A 2011.

38. Mehta, R. C.; Makino, E. T. H.; Sontis, S. D.; US2012177586-A1 2011.

39. Gao, W.; Cao, Y.; Bian, A.; CN101273957-A 2009.

40. Lefeuvre, L.; FR2997626-A1 2012.

41. Choi, Y. H.; Tae, C. B.; Lee, M. H.; Han, M. H.; 2015088154-A 2014.

42. Kolbe, L.; Traupe, L.; Traupe, B.; Filbry, A.; DE102006010589-A 2006.

43. Zhang, J.; CN104857499-A 2015.

44. Baudoin, C.; Menu, F.; Msika, P.; Naaimi, D.; FR2938192-A1 2008

45. Ge, H.; Seitz, E. P.; Doering, P.; US2015132416-A1 2015.

46. Ma, J. Y.; Chung, T. H.; Im, G. Y.; WO2012043920-A1 2010.

47. Bessada, S. M.; Barreira, J. C.; Oliveira, M. B. P.; Ind. Crop. Prod. 2015, 76, 604.

48. Keles, L. C.; Melo, N. I. d.; Aguiar, G. d. P.; Wakabayashi, K. A. L.; Carvalho, C. E. d.; Cunha, W. R.; Crotti, A. E. M.; Lopes, J. L. C.; Lopes, N. P.; Quim. Nova 2010, 33, 2245.

49. Edge, R.; McGarvey, D.; Truscott, T.; J. Photochem. Photobiol., B 1997, 41, 189.

50. Athar, M.; Nasir, S. M.; Afr. J. Biotechnol. 2005, 4, 36.

51. Park, P. J.; Lee, S. H.; Choe, E. G.; Lee, T. R., WO2015152552-A1 2014.

52. Daihyun, L.; Seonho, S., KR2014137540-A 2013.

53. Bo, Y. K.; Byoung, J. P.; Jin, J. K., KR2012020996-A 2010.

54. Laperdrix, C.; Robin, J. R., FR3011179-A1 2013.

55. Lee, C. C.; Rho, H. S.; Hwang, K. H.; Cho, G. Y.; WO2012067404-A2 2010.

56. Kapoor, V.; Nat. Prod. Radiance 2005, 4, 30.

57. Martin, R.; Paris, M.; Rathman, J. M.; Lavaud, B., WO2013102882-A2 2012.

58. Luo, Z.; CN103585268-A 2013.

59. Gedouin, A.; Vallee, R.; Morvan, P.; FR2984747-A1 2011.

60. Dubnikov, G.; WO2012099899-A2 2011.

61. Wang, Y.; Liu, Y.; Zhu, Y.; Song, Y.; CN101229114-A 2008

62. Doucet, O.; Pujos, M.; Robert, C.; Desriaux, E.; EP2641584-A1 2012.

63. Draelos, Z. D.; Clin. Dermatol. 2014, 32, 809.

64. Kim, H. K.; Lee, H. H.; Lee, S. M.; Noh, M. S.; KR2015115704-A 2014.

65. Rana, J.; Diwakar, G.; Scholten, J.; US2011212201-A1 2010.

66. Yin, T.; Dong, W.; CN103860645-A 2014.

67. Alimanti, A.; Matic, I.; EP2762131-A1 2013.

68. Jeong, J. B.; Hong, S. C.; Jeong, H. J.; Phytomedicine 2009, $16,85$.

69. Nishimura, M.; Ohkawara, T.; Kagami-Katsuyama, H.; Sekiguchi, S.; Taira, T.; Tsukada, M.; Shibata, H.; Nishihira, J.; J. Funct. Foods 2014, $7,487$.

70. Huang, D.-W.; Chung, C.-P.; Kuo, Y.-H.; Lin, Y.-L.; Chiang, W.; J. Agric. Food Chem. 2009, 57, 10651.

71. Etoh, H.; Murakami, K.; Yogoh, T.; Ishikawa, H.; Fukuyama, Y.; Tanaka, H.; Biosci. Biotechnol. Biochem. 2004, 68, 2616.

72. Wang, Y.; CN104707018-A 2013.

73. Miao, G.; CN104208503-A 2014.

74. Huang, Q.; Jia, T.; Zeng, H.; CN103877432-A 2013.

75. Koganov, M.; US2012121739-A1 2003.

76. Beyer, M.; Getzat, C.; Goddard, R. J.; Munk, C.; WO2014165490-A2 2013.

77. Rathi, V.; Rathi, J.; Tamizharasi, S.; Pathak, A.; Pharmacogn. Rev. 2008, $2,185$.

78. Rabinkov, A.; Miron, T.; Konstantinovski, L.; Wilchek, M.; Mirelman, D.; Weiner, L.; Biochim. Biophys. Acta 1998, 1379, 233.

79. Ankri, S.; Mirelman, D.; Microbes Infect. 1999, 1, 125. 
80. Amagase, H.; Petesch, B. L.; Matsuura, H.; Kasuga, S.; Itakura, Y.; $J$. Nutr. 2001, 131, 955S.

81. Tomatis, I.; WO2003035085-A 2001.

82. Hwang, J. K.; Hong, J. J.; Wook, W. S.; KR2015113717-A 2014.

83. Luecke, E.; Luecke, L.; Traeger, M.; DE102008011512-A1 2008.

84. Atika, S.; Soulimani, A.; WO2005097049-A1 2004.

85. Bylka, W.; Znajdek-Awiżeń, P.; Studzińska-Sroka, E.; Brzezińska, M.; Postepy Dermatologii I Alergologii 2013, 30, 46.

86. Cho, Y.; Kim, J.; Park, S.; Lee, B.; Pyo, H.; Park, H.; J. Cosmet. Sci. 2006, $57,11$.

87. Ketai, W.; Huitao, L.; Xingguo, C.; Yunkun, Z.; Zhide, H.; Talanta 2001, 54,753 .

88. Lyms, O. H.; KR1498691-B1 2014.

89. Zu, J.; CN103933089-A 2013.
90. Mi, R. K.; Yang, C. H.; KR2014058194-A 2012.

91. Ito, S.; Kong, F. Q.; Nojiri, W. Z.; Qin, W.; WO2010020165-A1 2008.

92. Liu, Z.; Liu, S.; CN101214209-A 2008.

93. Dhanavade, M. J.; Jalkute, C. B.; Ghosh, J. S.; Sonawane, K. D.; Brit. J. Pharm. Toxicol. 2011, 2, 119.

94. Zillich, O.; Schweiggert-Weisz, U.; Eisner, P.; Kerscher, M.; Int. J. Cosmet. Sci. 2015, 37, 455.

95. Yang, K. W.; Kim, S. C.; H., H. J.; Kim, S.; KR2015113271-A 2014

96. Modak, K. M.; Dongres, S.; WO2013103556-A1 2012.

97. Kwack, I. Y.; Yun, Y. N.; Park, T. H.; Kim, J. S.; WO2013081331-A1 2011.

98. Faller, J.; Gan, D.; Hines, M.; Mangos, L., US2011033562-A1 2008.

99. Fang, S.; CN103961440-A 2013.

100. Wagner, H.; Ulrich-Merzenich, G.; Phytomedicine 2009, 16, 97. 